\title{
A NeW View on the Monuments of the Rajajil Site
}

\author{
BY
}

\section{Mohamed Mahmoud Kacem}

\author{
Assistant Professor, History Department, the Faculty of Arts, cAin Shams University, Egypt
}

\begin{abstract}
[AR]

رؤية جديدة لآثار موقع الرجاجيل

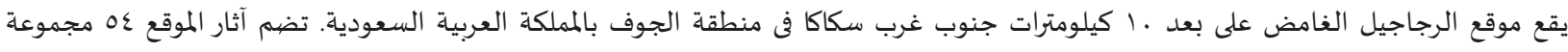

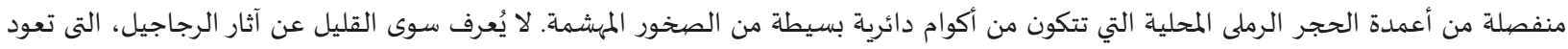

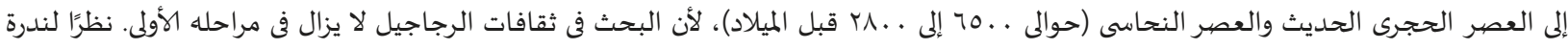

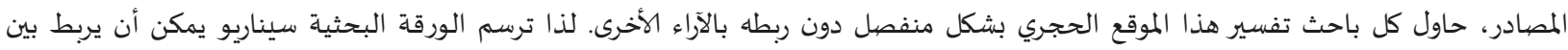

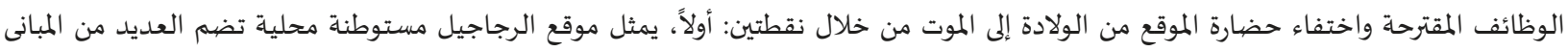

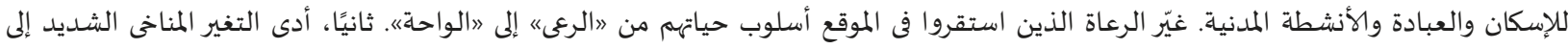

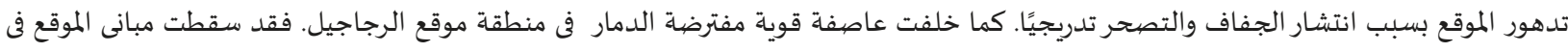

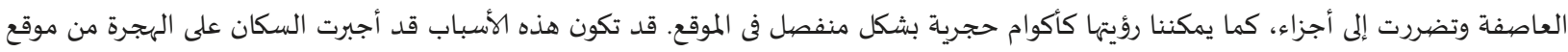

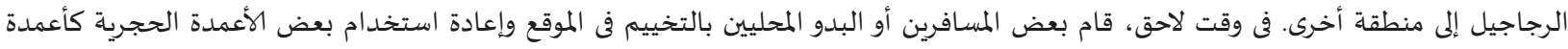

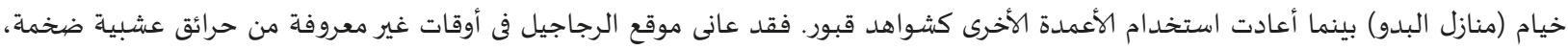
اعتيادية في المنطقة. يروى موقع الرجاجيل القصة الحقيقية لميلاد وموت حضارة محلية عاشت في صمت صحراء شبها الجزيرة العربية.
\end{abstract}

[EN] The enigmatic site of Rajajil is located precisely $10 \mathrm{~km}$ southwest of Sakaka in the Jawf region of the Kingdom of Saudi Arabia. The site monuments include fifty-four separated groups of local sandstone pillars comprising simple circular heaps of damaged boulders. Little is known about the Rajajil monuments, which date from the Neolithic and Chalcolithic eras (c. 6500 to 2800 BC), because research into the Rajajil Cultures is still in its early stages. Due to the scarcity of source material, every scholar tried to interpret this megalithic site separately without connecting it with the other views. The paper draws a scenario that could connect the suggested functions and the disappearance of the site's civilization from birth to death through two points: First, the Rajajil site represented a domestic settlement comprising many buildings for housing, worshipping, and civil activities. The shepherds who settled on the site changed their lifestyle from «pastoralization» to «oasisisation». Second, drastic climate change has led to the site's decline because of gradually spreading dryness and aridity. A supposed powerful storm left a trail of devastation in the area of the Rajajil site. The site buildings fell in the storm and were damaged into pieces, as we can see them as cairns separately in the location. Such reasons may have forced the settlers to migrate from the Rajajil site to another area. Later, some travellers or local Bedouins camped the site and reused some stone pillars as tent poles (Bedouins houses) while the other pillars were reused as gravestones. Rajajil suffered from massive grass fires, typical for the area, at unknown times. The Rajajil site tells the true story of the birth and death of a local civilisation that lived in the desert's silence of the Arabian Peninsula.

KEYWORDS: Stone pillars, Neolithic Age, Ancestor commemoration, Domestic buildings, pastoral tribes, Levant, Sakaka, pastoralization, oasisisation, Arabian Peninsula. 


\section{INTRODUCTION}

The Arabian Saudi Peninsula has many mysterious sites characterized by stonebuilt structures called by archaeologists as cairns, megalithic, or mustatils, and they are known to the Bedouin as the "works of the ancient people»1.

Modern human activities have destroyed many archaeological structures scattered throughout the area. One of these sites is the enigmatic site of Rajajil that is located 10 $\mathrm{km}$ southwest of Sakaka in the Jawf region. The unique stone pillars of this site could be dated to the late sixth and early fifth millennium $\mathrm{BC}^{2}$, but a few shreds around the stone pillars have raised the possibility of a fourth millennium $\mathrm{BC}$ date ${ }^{3}$.

Because of the interest of the Saudi government in local heritage, the Saudi American Archaeological Mission carried out excavations in the 1970s under the supervision of Zarins. He summarized his study by saying that «the Rajajil site represented the focal point of a semi-sedentary village with a tumuli area and a central ceremonial complex in the Sakaka basin» ${ }^{4}$. Thus, Zarin's early articles have influenced several scholars who stick to his point of view concerning the Rajajil site. Since 2012, the site has been subject to planned investigations by a joint project of the Saudi Commission for Tourism and Antiquities, Riyadh. The results showed that the pillars were erected on the original sand layer of the site, indicating that there are no old foundations at the bottom of this structure.

Additionally, no bones or funeral equipment could help scholars understand the purpose of erecting that site ${ }^{5}$. Recently, Almushawh studied the structural remains of the site for her $\mathrm{PhD}$ and concluded that the site has an astronomical function but with no factual evidence ${ }^{6}$. Therefore, the mystery remains unsolved, as no clear layout of the site's structures is defined ${ }^{7}$. Every previous study about the site's function tried to prove its view separately without connecting it with the other views. Based on available discoveries, this paper proposes a view that connects between the function and the end reason of the site civilization of Rajajil in addition to a specific scenario to the site life story of Rajajil. It depends on the analysis of the various hypothesizes in some detail to bring these views closer together since we are at the beginning of the research for the Rajajil Cultures, as we shall discuss below.

\footnotetext{
${ }^{1}$ KeNNEDY 2011: 3185-3186; KeNNEDY 2020: 120; THOMAS 2021: 2.

2 GEBEL 2016: 87.

${ }^{3}$ ZARINS 1979: 74, 77; AL-MUAIKEL 1988: 67, 70; MAGEE 2014: 85; PURSCHWITZ 2017: 302.

4 ZARINS 1979: 76.

${ }^{5}$ GEBEL \& MAHASNEH 2013: 127-158.

${ }^{6}$ AlmuSHAWH : 2016: 220.

7 KHAN 2014: 551.
} 


\section{DESCRIPTION}

The current name of this site Rajajil, is derived from the area's local inhabitants. It is an abandoned word that means «standing men» in the local pronunciation. They have chosen this name because the stone pillars appeared to be men standing side-by-

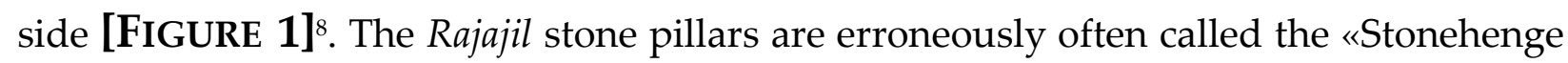
of Arabia» compared to the «Stonehenge of England» in touristic contexts 9 .

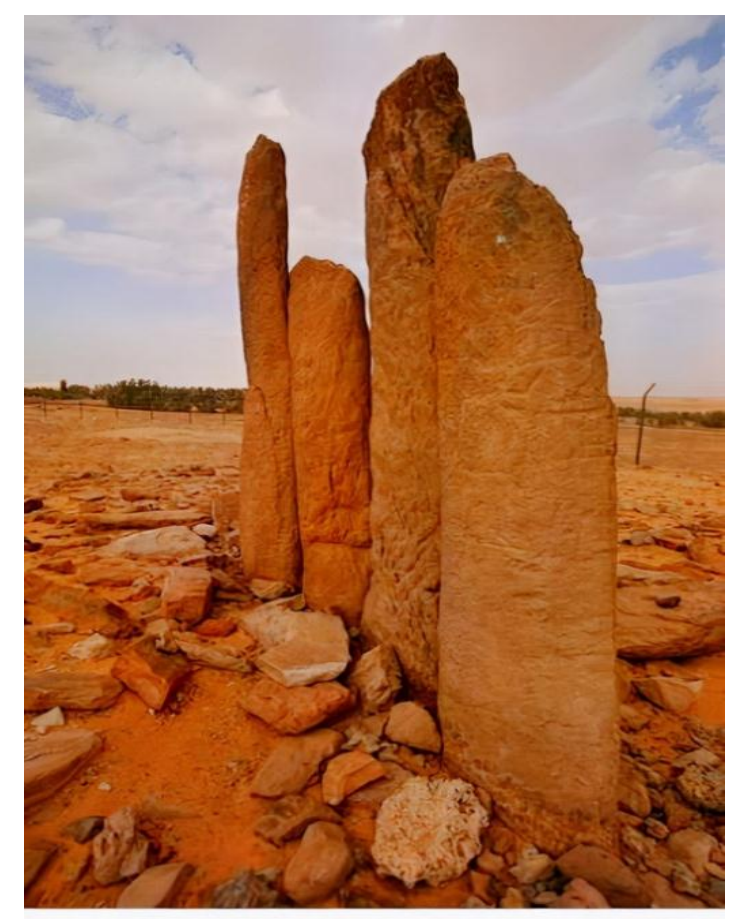

[FIGURE 1]. The standing stone pillars of the Rajajil site.

Https://www.skyscrapercity.com/threads/anciant-saudi-arabia.865888, Accessed on June 12, 2020.

The site of Rajajil is located precisely $10 \mathrm{~km}$ southwest of Sakaka in the Jawf region of the Kingdom of Saudi Arabia (between Longitude E 40 13' 13" and Latitude №. $29^{\circ}$ $\left.48^{\prime} 45^{\prime \prime}\right)$. It is on a low sandstone terrace $600 \mathrm{~m}$ above sea level ${ }^{10}$. The site includes fiftyfour separated groups of local sandstone pillars comprising simple circular heaps of damaged stones. These groups are related to an irregular circle that extends about eight hundred $\mathrm{m} 2$ in diameter. Each group comprises two to ten pillars ${ }^{11}$. Curiously, eleven groups still have preserved stone pillars long enough to be inserted into the ground to have a solid foundation. The pillars are nearly $3.5 \mathrm{~m}$ in height and $75 \mathrm{~cm}$ in width. They are standing, sloping, broken or lying above the ground. A few pillars bear some mysterious figures and Thamudic signs ${ }^{12}$. The vast surrounding territory succumbed to

\footnotetext{
${ }^{8}$ LEWIS 2013: 9, 49.

9 GEBEL 2017: 1.

${ }^{10}$ ALMUSHAWH 2018: 4.

${ }^{11}$ GEBEL 2013: 119, Fig.1.

12 ZARINS 1979: 74-76.
} 
modern agricultural and building activities that unfortunately led to the partial destruction of the archaeological area.

\section{Previous Hypothesizes AND STUdies}

The megalithic structures' erection required high physical ability from the ancient inhabitants, who had specific views, beliefs, and contemplative viewpoints on the world. Now, we can present a review of other researchers' works on the site function. Six hypotheses try to decipher the enigma of these standing stone pillars of the Rajajil site:

1. The Rajajil site has religious significance. Its remains have a circular dimension rounded around an altar or a temple in the middle of the site. Furthermore, there are Thamudic signs of animals (camel? ibex? oryx? cheetah?), riding and (socializing) human scenes (dancing?) on the northern side of the stone pillars [FIGURE 2] ${ }^{13}$. Besides, no other site is close to the Rajajil site's pillared structure in the entire Northern Province. Thus, the site may serve as a communal meeting place for certain diverse social groups to conduct ethno religious roles ${ }^{14}$.

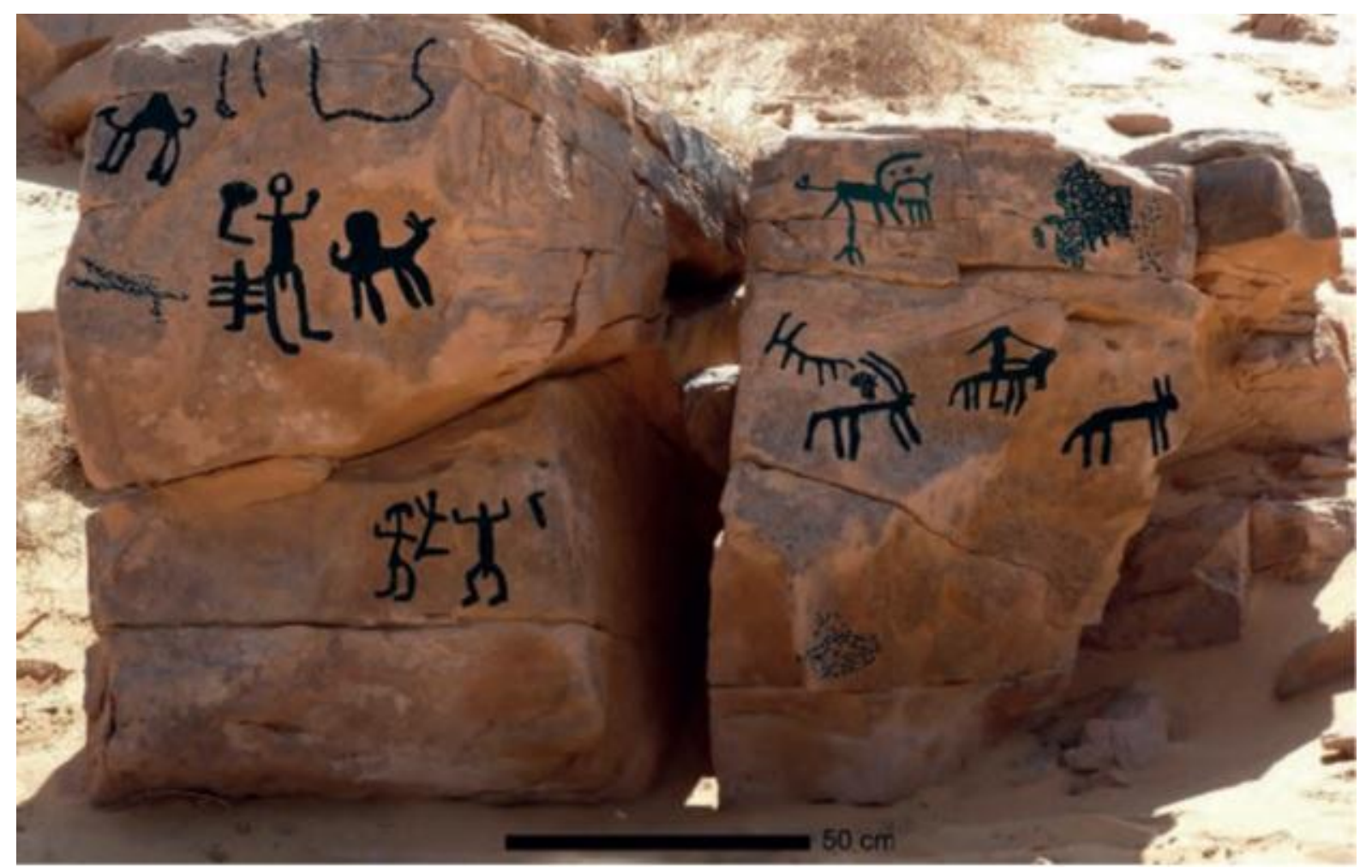

[FIGURE 2]: Thamudic depictions of animals and (socializing) human scenes GEBEL 2016: FIG.19.

In contrast, the stone pillars have no identification signs to consider as religious symbols. There are no remains of sacrificial offerings discovered on this site.

\footnotetext{
13 GEBEL 2016: 105.

14 ZARINS 1979: 76.
} 


\section{Mohamed Mahmoud Kacem}

Additionally, the travellers of the later times may add some petroglyphic depictions on the caravans' road across the desert near the Rajajil site. At three sites south of Sakaka near the Rajajil site, Khalil Ibrahim al-Muaqil discovered more than 150 early Arabic inscriptions written in the Thamudic script. They were dated by Suleiman Adhdhyyb between the third century $\mathrm{BC}$ and the third century $\mathrm{AD}^{15}$.

2. The Rajajil site had an astronomical function because its residents aligned six rows of stone pillars towards the rising sun and the others to the northward south, where the Arctic star 'Capricorn' ${ }^{16}$. Furthermore, the Rajajil site belonged to the dawn of agriculture practices during the Neolithic Age and later, which required astronomical knowledge ${ }^{17}$. Moreover, one of the so-called Thamudic signs is an arrow directed at the sky. These signs of celestial objects reflect the knowledge of astronomy ${ }^{18}$.

The previous hypothesis is based mainly on extrapolations, inferences, cautious empirical experiments, and uncertain measurements. It is noteworthy that some other damaged stone pillars are next to these six rows of stone pillars. Therefore, the suggestion that all these pillars follow a specific axis is not proven ${ }^{19}$. Hence, the occupants of the Rajajil site did not register any signs of celestial objects on these standing stone pillars during the Neolithic age. Furthermore, those scholars did not explain how the ancient dwellers acquired their knowledge of astronomy in ancient times, and they provided no evidence to back up their claim. For example, Almushawh wrote: «the significant North-South adjustments of these stone pillars is a preliminary study and just tries to predict a proper sample for a future full-scale project that improves various aspects of this hypothesis in the Saudi Arabian megalithic sites» ${ }^{20}$.

3. The dwellers used the stone pillars of the Rajajil site as symbols associated with burial $^{21}$. They inserted these stone pillars into the ground side-by-side and extended them along the eastwards-west axis of the site. The cairns of the Rajajil site, together with the standing pillars, represent the ruins of destroyed rooms multi-chambered dedicated to burial. These burial chambers have a ceremonial role rather than their original function as a cemetery. They provided a focal point for ancestral identity ${ }^{22}$. We need to compare the Rajajil site with the other related locations in the Arabian Peninsula to sketch the primary features of this scene. In the areas of the Lithic Ages (as the alMidaman and Bani-Murra sites), which were contemporary to the Rajajil site, the chain

\footnotetext{
${ }^{15}$ ADH-DHYYв 2002: 3.

16 MAGEE 2014: 85.

${ }^{17}$ AlMUSHAWH 2018: 6-7.

${ }^{18}$ ALMUSHAWH 2016: 4-5, 166; 2018, 5-7, Figs.5, 8-11.

${ }^{19}$ GEBEL \& MAHASNEH 2009: 1-9.

${ }^{20}$ ALMUSHAWH 2018: 7.

${ }^{21}$ KEALL 1998: 145.

22 GEBEL 2016: 89-90.
} 
of isolated and clustered circular structures around these pillars related to funeral ceremonies $^{23}$. On the Yemeni Tihama coast, the seven funerary or cultic sites of alMidamman have stone pillars inserted into the ground. This feature could show that successive generations used them as funerary stelae in the early ages. There are similarities in use between the standing stone pillars of the Rajajil site and these sites $^{24}$. In that context, the absence of human and animal remains at the Rajajil site can be attributed to the following thoughts: 1) Peculiar funerary rituals such as incineration did not preserve the body but preserved charcoal and ash. 2) At funeral homes, human skeletal remains are rarely preserved. 3) The disappearance of grave goods was caused by hundreds of years of illegal looting of archaeological remains. Accordingly, the Bedouins used these stone pillars not only as gravestones but also as memorial pillars where some celebrations of the ancestors were held to perform funeral practices ${ }^{25}$. The generations visited these sacred places to regain the glories of their ancestors, who had a particular rank in their tribes' memory. Thus, these sites have played an essential role in the social transactions and tribal identity associated with ancestor commemoration ${ }^{26}$. The pastoral tribes met in places for watering flocks, enabling semi-permanent settlements.

On the other hand, the funerary structures must relate to civil sites where the inhabitants lived and buried their dead in their necropolis. If these standing pillars represented the remains of funeral chambers or gravestones, where were the houses of the living ones? The scholars did not discover any signs engraved on the stone pillars that could identify those ancestors. We can give a specific view in that context. See infra.

4. The elite of the Pastoral tribes constructed such stone pillars to symbolize their unification according to the tribal confederation ideology and identity. Thus, these sites represented centers for the festivals of agreements and treaties ${ }^{27}$. This latter opinion has no evidence of tribal identities or celebrations performed on the Rajajil site. It is noteworthy that the Bedouins of every tribe had their festivals or rituals.

5. The stone pillars refer to the safest route to travel because this site is on the crosstrade routes between the Levant and Mesopotamia ${ }^{28}$. One cannot ignore the Bronze Age necropolis of Tamriyat, northward-east of Sakaka, or the Tabuk Region, where turret tombs punctuate the valley slopes to define the ancient routes. If the tombs are many, this could prove the continued usage of these tombs as route signs throughout the

\footnotetext{
${ }^{23}$ GEBEL \& MAHASNEH: 2013, 135.

${ }^{24}$ KHALIDI: $2008,6,18$.

${ }^{25}$ GEBEL 2009: 1-2; 2016: 83.

${ }^{26}$ GEBEL \& WELLBROCK 2019: 251.

27 AL-MUAIKEL 1988: 71; NEWTON \& ZARINS 2000: 171.

${ }^{28}$ GEBEL 2017: 9, 12.
} 
centuries. Many megalithic structures flank communicating routes known as «funerary avenues» between the oases and the hinterland ${ }^{29}$.

This hypothesis is not accepted because the caravans did not need this considerable number of stone pillars in the same place.

\section{NEW VIEW}

Now, because of the differences set forth above between the previous hypotheses, we can gather some other shreds of evidence that gives us a better idea of the Rajajil stone pillars' function, as follows:

1. Pottery shreds of the Rajajil site connected to a general type with a variable buff to yellow or light brown slip. Other shreds were dull brown or reddish. Although Zarins interprets these features to the prolonged exposure to the heat at the surface ${ }^{30}$, I propose they were signs of burning many times to prepare the food. Moreover, we note burning signs appeared at the bottom of some pillars' sides near the edge of the cairns [FIGURE 3]. These signs showed the residents prepared the food on a specific side where a kitchen was at the end of the house, and they might have used palm fronds or animal dung as fire materials for stoves. Unlike wood, these materials leave no charcoal fragments after combustion ${ }^{31}$.

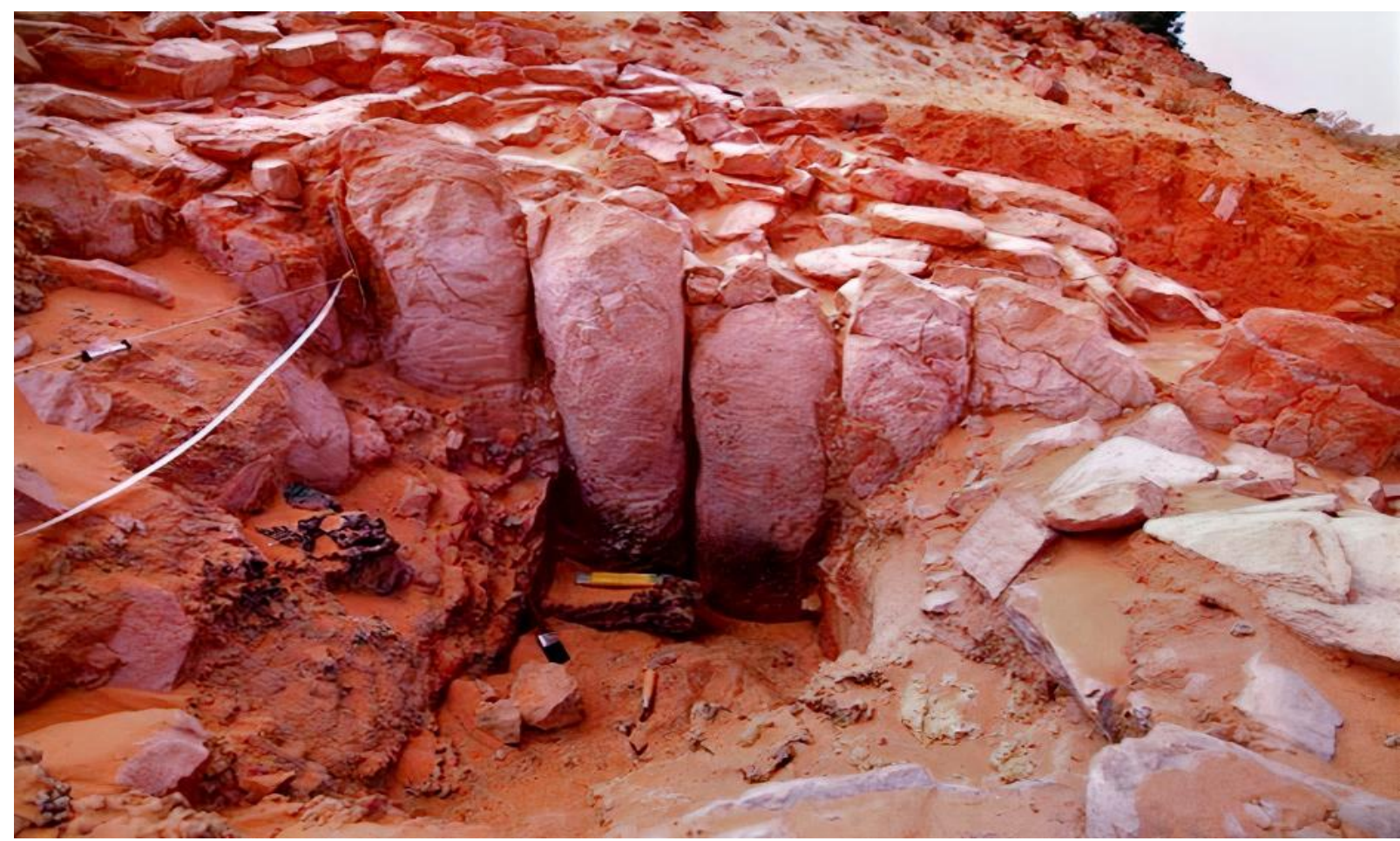

[FIGURE 3]: The burning remains appear clearly on the lower part of some stone pillars.

Https://english.alarabiya.net/life-style/art-and-culture/2018/09/19/Did-archeologists-unveil-the-secretof-the-man-like-columns-in-Saudi-Arabia, Accessed on April 15 / 2019.

\footnotetext{
${ }^{29}$ HAUSLEITER \& ZUR 2016: 165.

30 ZARINS 1979: 75.

31 GEBEL 2017: 14.
} 
2. Pottery was a fundamental phenomenon for the commercial exchange among the kingdoms of the Ancient Near East ${ }^{32}$. Overall, the nature of the pottery at the Rajajil site is like the pottery discovered at other sites in Sinai, Negev, Palestine, and Transjordan. The industry was homogeneous in typology and technique among these sites because people had commercial relations ${ }^{33}$. The trade extended between the agricultural communities from Sinai to the northeast of the Arabian Peninsula (Jawf/Naqab), where Rajajil is located ${ }^{34}$. Rajajil played a significant role in the trade connections between Mesopotamia and the Levant ${ }^{35}$.

3. In the center of the site, scattered remains of pillars lie on a high hill. The layout of this rectangular structure shows a building divided into courts and side chambers. The standing stone pillars support the roof [FIGURE 4]. This building could represent a temple or a palace for the ruler that was overlooking the site.

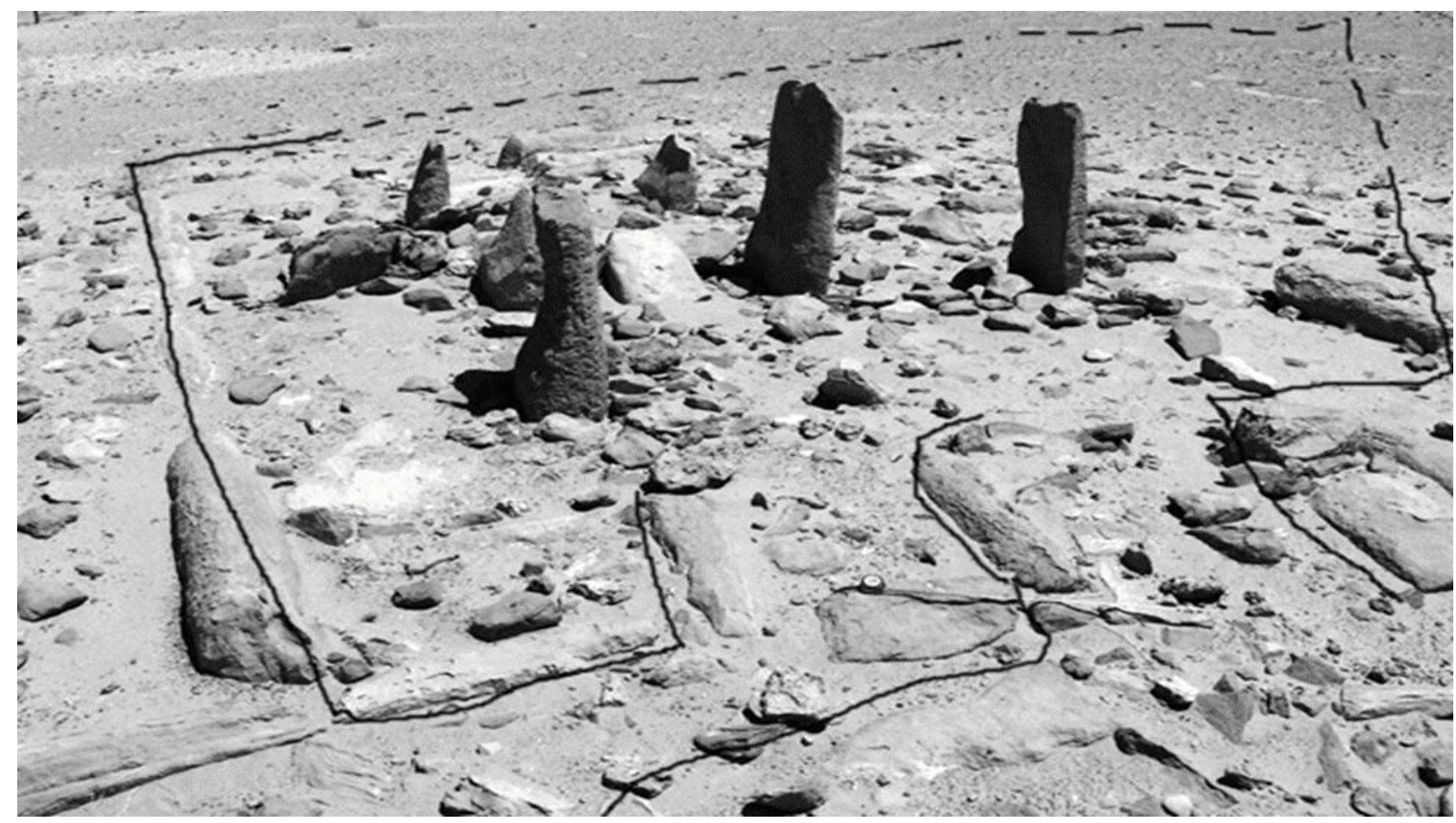

[FIGURE 4]: Remains of pillars and debris on the high hill of Rajajil.

GEBEL 2013: 155, FIG.27.

4. A team from the Department of Antiquities excavated one structure at the Rajajil site in 1977. The structure is composed of four wide slabs of sandstone, and its design almost forms the shape of a horseshoe. The stone pillars rested on the firm layer of the ground $^{36}$, so the inhabitants had to erect their buildings' pillars on the rocky floor.

\footnotetext{
32 GEBEL \& WELLBROCK 2019: 257.

33 ZARINS 1979: 75.

34 GEBEL \& MAHASNEH 2013: 142.

35 Al-MUAIKEL 1988: 65, 87.

36 AL-MUAIKEL 1988: 65.
} 
5. According to the photo-analysis of Google Earth, the Rajajil site is located on a torrent shore of freshwater [FIGURE 5]. The inhabitants used this river as a source of freshwater ${ }^{37}$. Additionally, this river deposited sediment along its two edges. Then, these available agricultural requirements made the Rajajil land ideal for stability and residence. Evidently, a cluster of 125 hearths identified the landscape of the Jubbah site that is situated on the coast of an inter-dune lake in the western Nefud desert ${ }^{38}$. We can suggest that this torrent of water gushed into this lake, where the residents settled on the two river edges and its lake.

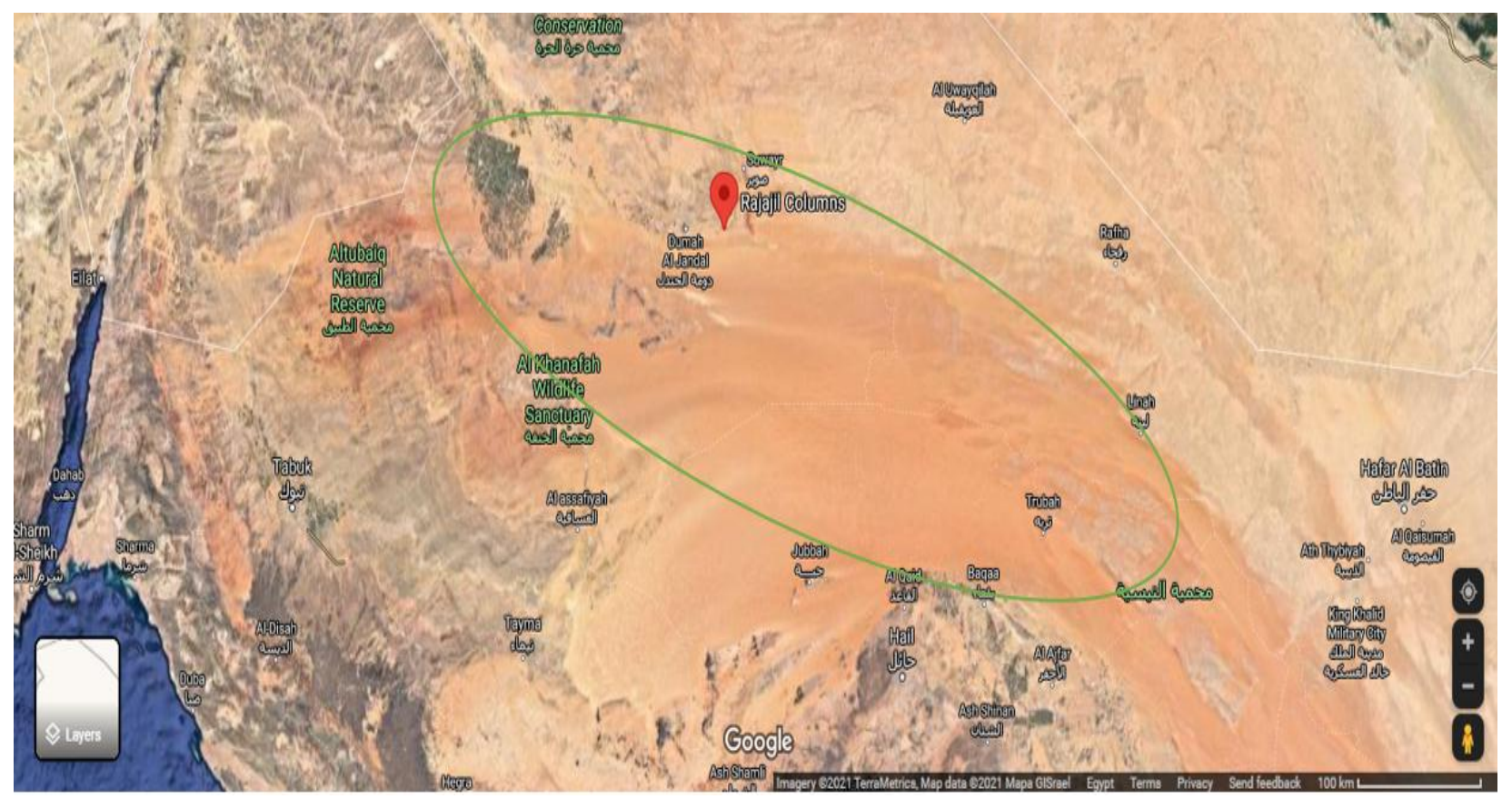

[FIGURE 5]: The Rajajil site locates on the shore of a torrent shore of the freshwater Rajajil Columns - Google Maps

6. The Rajajil site is on a rocky hill of sandstone to avoid the risk of destruction because of the repercussions of flood torrents. Therefore, the mild slope of this hillside was leveled to be suitable for building dwellings.

7. By comparing the landscapes of the Rajajil site with the contemporaneous proto-oases of the Arabian Peninsula, such as al-Hait in central Arabia, or Khawlan at-Tiyal in Yemen, the standing pillars are the central architectural feature. In such cases, the main layout of these standing pillars shows rooms that could be quite large (up to 9-10 $\mathrm{m}$ long). These rooms have one or two stone pillars to carry the roof. Large orthostats often frame doorways that may also have stone thresholds and open central space ${ }^{39}$.

Similarly, the inhabitants of the Rajajil site used these standing pillars as columns in domestic buildings because the sturdy trunks were suitable for carrying heavy roofs. Furthermore, the height is appropriate for living [FIGURE 6]. Those residents regularly

\footnotetext{
37 LORETO 2013: 213.

38 GUAGNIN 2020: 108.

39 EDENS 1999: 122.
} 
stacked many pillars to represent the walls of buildings. The cairns of the Rajajil site could also define multi-room structures with enclosed courtyards.

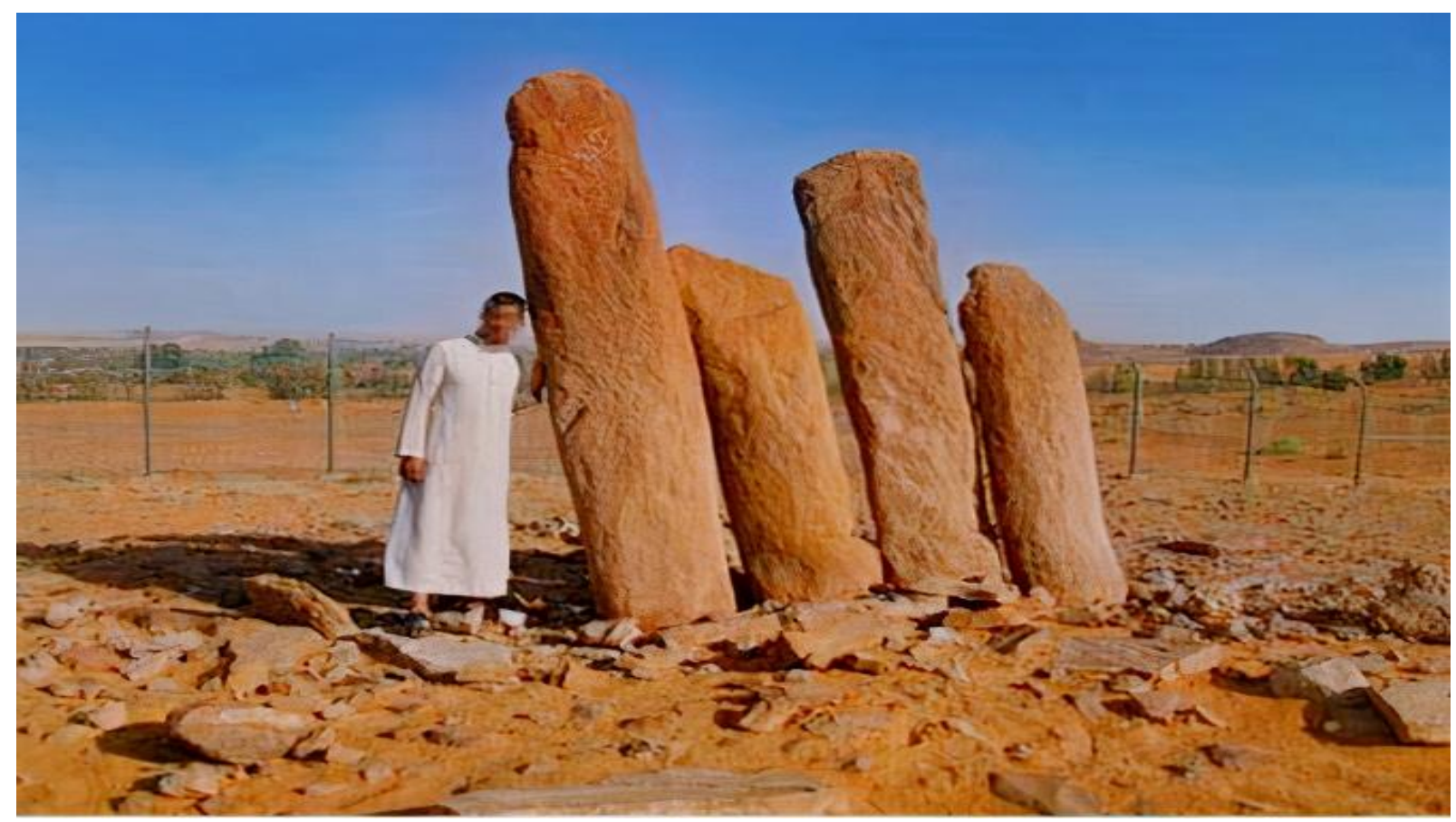

[FIGURE 6]: The height of the Rajajil stone pillars is fit for carrying a roof. Http://www.alrassxp.com/forum/t64779.html, Accessed on June 10/2020.

8. Hans-Georg K. Gebel (Freie Universität, Berlin) discovered seventy circular pits on the south slope of the Rajajil site [FIGURE 7]. They included human bones and grave goods, such as fan scrapers, mace heads/weights, sea-shell bracelets, and beads ${ }^{40}$. At one of them, he discovered a paved passage flanked by two benches for resting and leading up the hill ${ }^{41}$. The people used these pits as local graves because their number and the discoveries could show a traditional burial field on the site. There is no proof that the south slope and the standing stone monuments were contemporaneous. However, comparative evidence from the Funerary Landscape of the Taymā oasis shows extended burial areas around the oasis settlements. These burial areas existed to the south of the Tayma a oasis, like those pits at the Rajajil site ${ }^{42}$. The funerary architecture still needs a systematic distribution map to be drawn for the Rajajil site.

\footnotetext{
${ }^{40}$ GEBEL 2017: 14.

${ }^{41}$ GEBEL 2013: 120; 2016: 87, 90.

${ }^{42}$ HAUSLEITER \& ZUR 2016: 140, 158.
} 


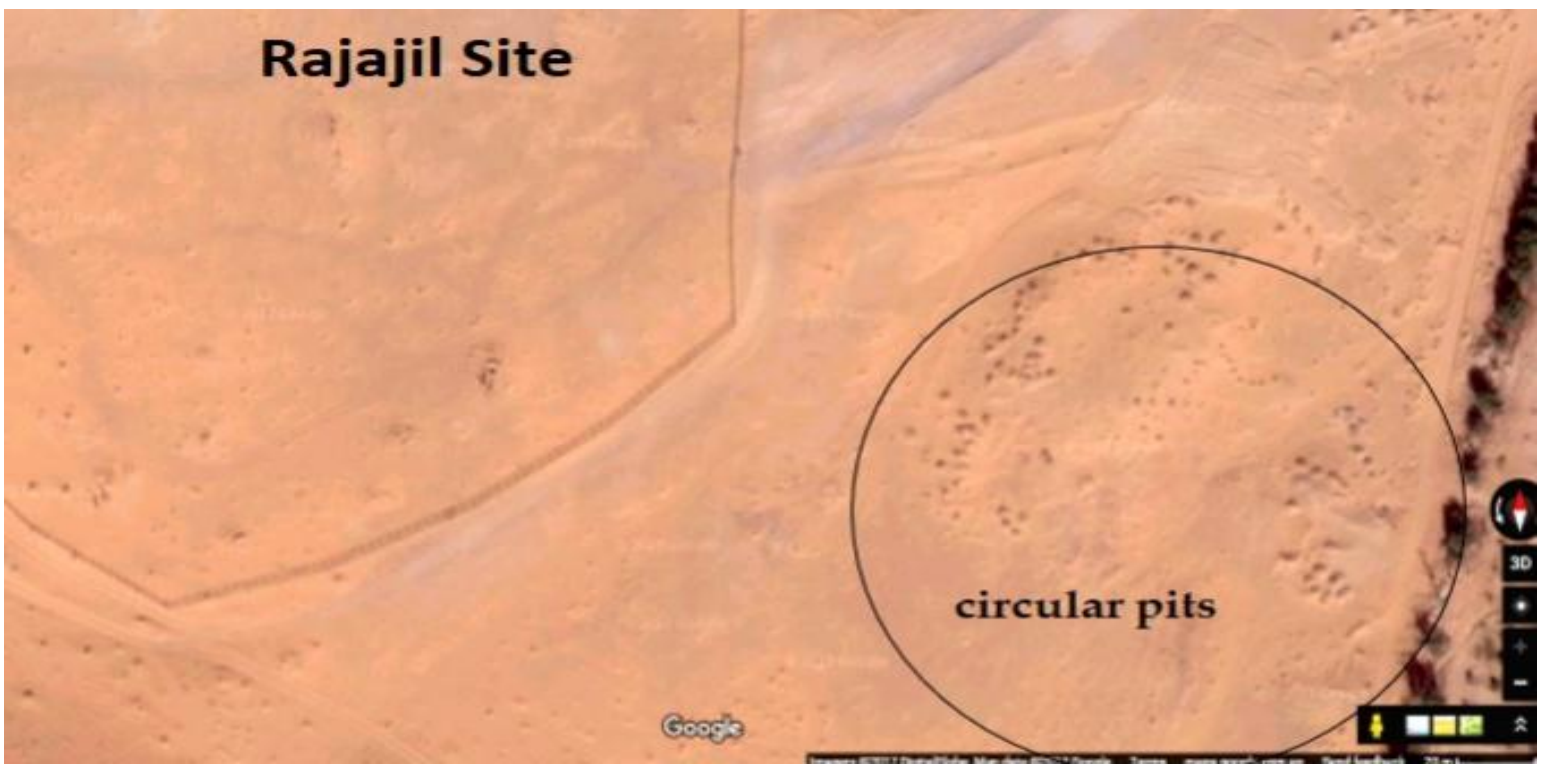

[FIGURE 7]: Some 70 visible pits are on the south slope of the site Rajajil Columns - Google Maps

For all the reasons mentioned above, we can define the stone pillars of the Rajajil site as house columns. All the previous points prove that the site was a settlement for housing. Its inhabitants achieved many agricultural and herding crafts activities, either on the edges of its torrent of freshwater or in wells in the surrounding desert. From this point of view, we can offer more opportunities for observations concerning the landscape of the Rajajil site, which witnessed the growth of oasis life and modest agricultural intensification, setting a course toward complex societies.

\section{DISCUSSION}

The Saudi-German Project at the Rajajil site highlighted the landscapes of mobile pastoralists during the early occupational phases. Here, the field investigations in the northwest of Saudi Arabia extended to previous research conducted in Syria and Jordan. The results of such works added another dimension to ancient Near Eastern history. We can grasp distinct parts of the Peninsula's hitherto underappreciated environmental diversity during the critical transitional phases from pastoral to settled oases of the Middle-to-Late Bronze Age.

The proper definition of «landscape» is a natural environment changed by the cultural behavior of human beings. The monuments of these archaeological sites resulted from the domestication of organized societies. While farming was opportunistic and seasonal in this area, the residents did not see it in the same way. This landscape served as the focal point of their social lives. Their living experience taught them how to carve out their niche, developing modes of existence in these areas. It is essential to show that the landscape that now characterizes the Rajajil site has changed since its first human settlement, as the landscape we live in is still growing and changing. 
Pastoral tribes have followed a central transhumance pattern before colonization since the late sixth millennium. Several families assembled on longer-term sites in winter, and they dispersed in the dry summer to the ephemeral locations. Then, they tried to settle on sites with the fundaments of life, such as fresh water and fertile soil. These sites seem like oases in the desert. The clusters included houses, pens, and storage facilities. Although the Neolithic period coincided with increased homes and inhabitants, the inventory rates of agricultural production remained low, below the local landscape capacity, until the Early Bronze Age ${ }^{43}$. Now, we can draw the scenario of what happened to the Rajajil site into five points:

The first point is to sketch the development of the settlements of the fifth millennium BC. After the climate had become drier and warmer, the pastoral tribes settled in the hydrological favorable areas during the so-called Rapid Climate Change (6000 to 5200/5000 BP) ${ }^{44}$. The Rajajil ground has a rich clay soil suitable for agriculture until now [FIGURE 8], and it looked like an oasis in the middle of the desert. These necessities of life helped people gradually settle down on the site. They fed the flocks at watering locations, built pens and human shelters, practiced their funeral traditions, demonstrated identity by commemorating ancestral bonds, and mediated social and economic relations with their neighbors ${ }^{45}$.

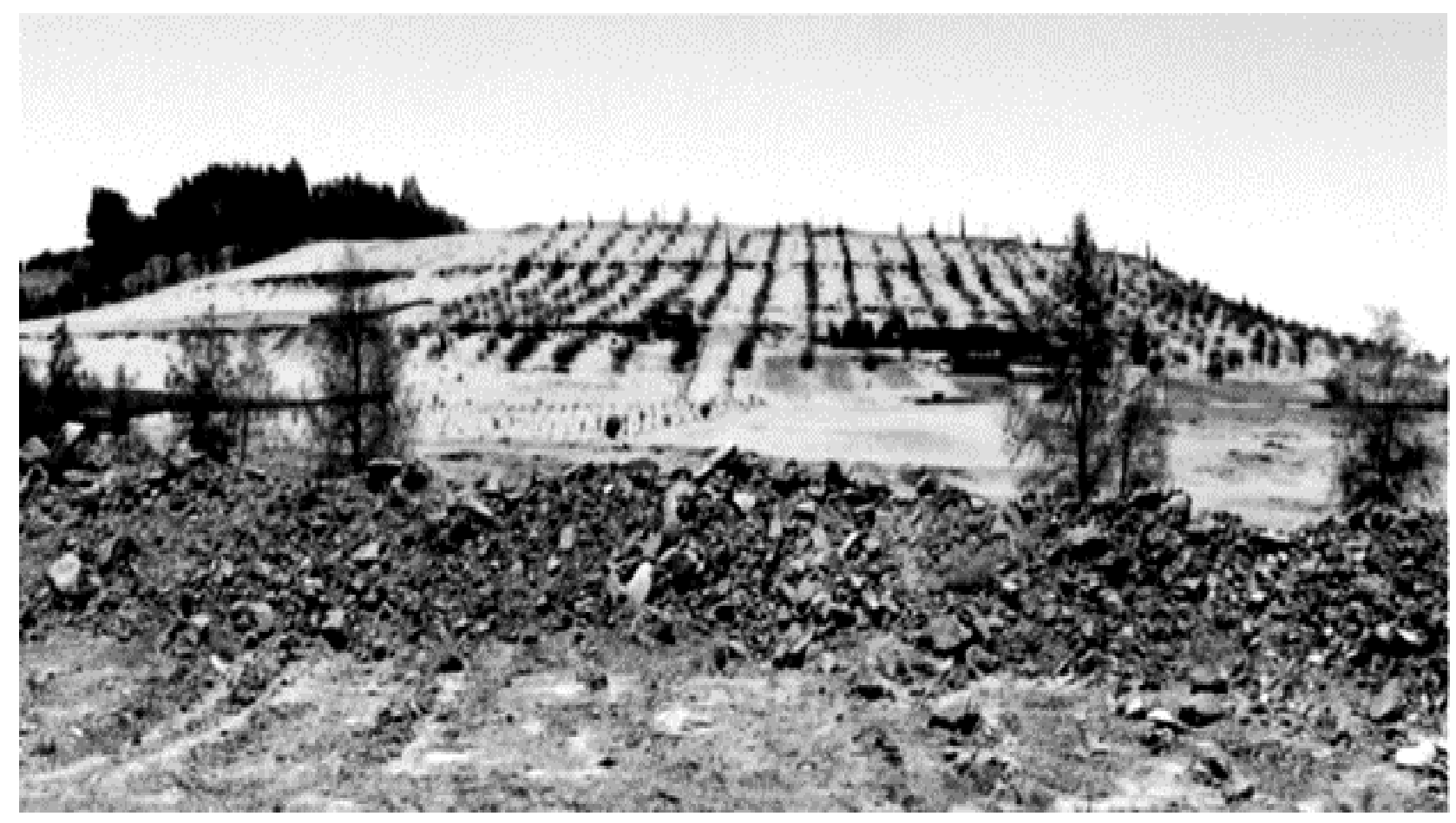

[FIGURE 8]: Bulldozed land surfaces preparing new fields, and an olive yard on the dunes sustained by dripper irrigation with water from deep wells; near Rajajil.

GEBEL \& WELLBROCK 2019: 253, Fig.12.7.

\footnotetext{
${ }^{43}$ GUAGNIN 2020: 105.

${ }^{44}$ CHIOTIS 2019: 19.

${ }^{45}$ GEBEL \& MAHASNEH 2013: 132.
} 


\section{Mohamed Mahmoud Kacem}

This new socio-economy must have developed gradually and regionally in diverse ways from the previous pastoral cultures. The people of the Rajajil site began the transition from a hunter-gathering tribe «pastoralization» to a sedentary and agricultural lifestyle «oasisation». The residents of the Rajajil site developed a distinctive domestic, ritual, and funerary architectural tradition characterized by standing stones. The transition of the former pastoral hydraulic and sepulchral ecosystems may have begun in the fifth millennium BC (the period corresponding to the Chalcolithic in the Levant), establishing proto-oases at favorite hydrological locations like the Rajajil site. This trajectory, however, does not imply that the use of pastoral steppes ceased during oasis periods, but rather that it continued as a subactivity of life ${ }^{46}$.

Furthermore, the residents of Rajajil took advantage of their privileged location at the crossroads of trade routes that connected Egypt, the Arabian Peninsula, Syria, and Mesopotamia during the Prehistoric Period. They exchanged pottery and agricultural products with their neighbors in the Fertile Crescent, the Levant, and the Arabian Peninsula tribes. This view would show that the Arabian Peninsula was more appropriate for habitation than it would seem nowadays. The survey of the Northern Province of the Arabian Peninsula identified twelve Neolithic and Chalcolithic sites in Jubbah $^{47}$. Many settlements, such as Rajajil, Rizqeh, and Qulban Banī Murra, flourished along the edges of the great deserts during the Stone Ages ${ }^{48}$. At least these sites had ceremonial buildings, residential structures, graves, and hydraulic installations ${ }^{49}$.

The Rajajil site includes most of the previous elements too. It is characterized by a succession of endorheic depressions trapping sediments and water ${ }^{50}$. The economy of the Rajajil became wealthy because of fast-growing agricultural production and flourishing commercial relations. Thus, it had the power to erect unique buildings of sandstone that were collected from the immediate landscape. Moreover, funeral pits existed commonly around the settlement of the Rajajil, like any typical settlement in the Ancient Near East.

The second point suggests that the Rajajil site's stone pillars were architectural elements of buildings dedicated to roofs. Every separated cairn of the site represents the ruins of a separate building. The problem is that the site landscape of Rajajil, expected to have covered several square $\mathrm{km}$, was destroyed by modern agricultural development before the pillared areas were fenced, so that little can be said about its domestic quarters. Scholars did not define the main layout of such buildings until now. We can

\footnotetext{
${ }^{46}$ GEBEL \& WELLBROCK 2019: 251.

${ }^{47}$ GUAGNIN 2020: 106.

${ }^{48}$ GEBEL \& MAHASNEH 2013: 132.

49 GEBEL \& WELLBROCK 2019: 257.

50 CHARBONNIER 2019: 223.
} 
suggest a layout of the traditional building on the site. Ground plans of houses in the earlier Rajajil Culture were identified from the best-known location of Qulban Bani Murra in Northern Arabia. Every building may comprise an oval or sub-rectangular one-room, often separated by one or two pairs of stone pillars. The inhabitants of the Rajajil reused stone pillars as gates, lintels, door jambs, and columns in their domestic structures. The settlers of the Rajajil site used organic materials like palm branches to erect roofs and doors. These materials decomposed or were burned by the fire disaster. Rajajil suffered from massive grass fires, typical for the area, at unknown times. Traces of these fire blasts were found at many spots, turning sand even into lumps of glazed material.

After transitioning from a Bedouin lifestyle to an oasis lifestyle, the residents erected the walls and columns of the domestic buildings out of local sandstone. They practice their social activities and the traditional tasks of daily life inside these buildings. They used many fan scrapers and other stone tools as house tools. The house interiors still provided some opportunities for concealment, including hoarding and preparing the food. Therefore, we observe the remains of burning on the lower parts of the stone pillars.

The third point is devoted to discussing the reasons for the inhabitants' migration away from the site. When the climate changes get drier and warmer, the local climate is harsh with seasonal and annual variations. The drastic climate change led the site to decline because of the spread of dryness and aridity gradually. Additionally, an expected powerful storm left a trail of devastation in the area of the Rajajil site. The site buildings fell in the storm and were damaged into pieces, as we can see them as falling into pieces as we can see them as falling into pieces separately in the location. The evidence comes from analyzing two aspects: a) The buildings' solid structural elements, such as the stone pillars, withstand the wind and continue to stand, slope, or lie on the ground [FIGURE 9]. These conditions might have caused severe storms of sand that covered the clay soil of the site. The event also caused the disappearance of arable soil and the obliteration of fresh torrents. b) the lack of many everyday artefacts among the cairns. They may have drifted away to somewhere nearby because their weight is light against the fierce winds. c) The Rajajil site's ground layers are made up of a thin layer of lacustrine diatomite sediments. The sands have covered this layer for a long time because of the fierce winds ${ }^{51}$.

51 LORETO 2013: 217, FIG.5. 


\section{Mohamed Mahmoud Kacem}

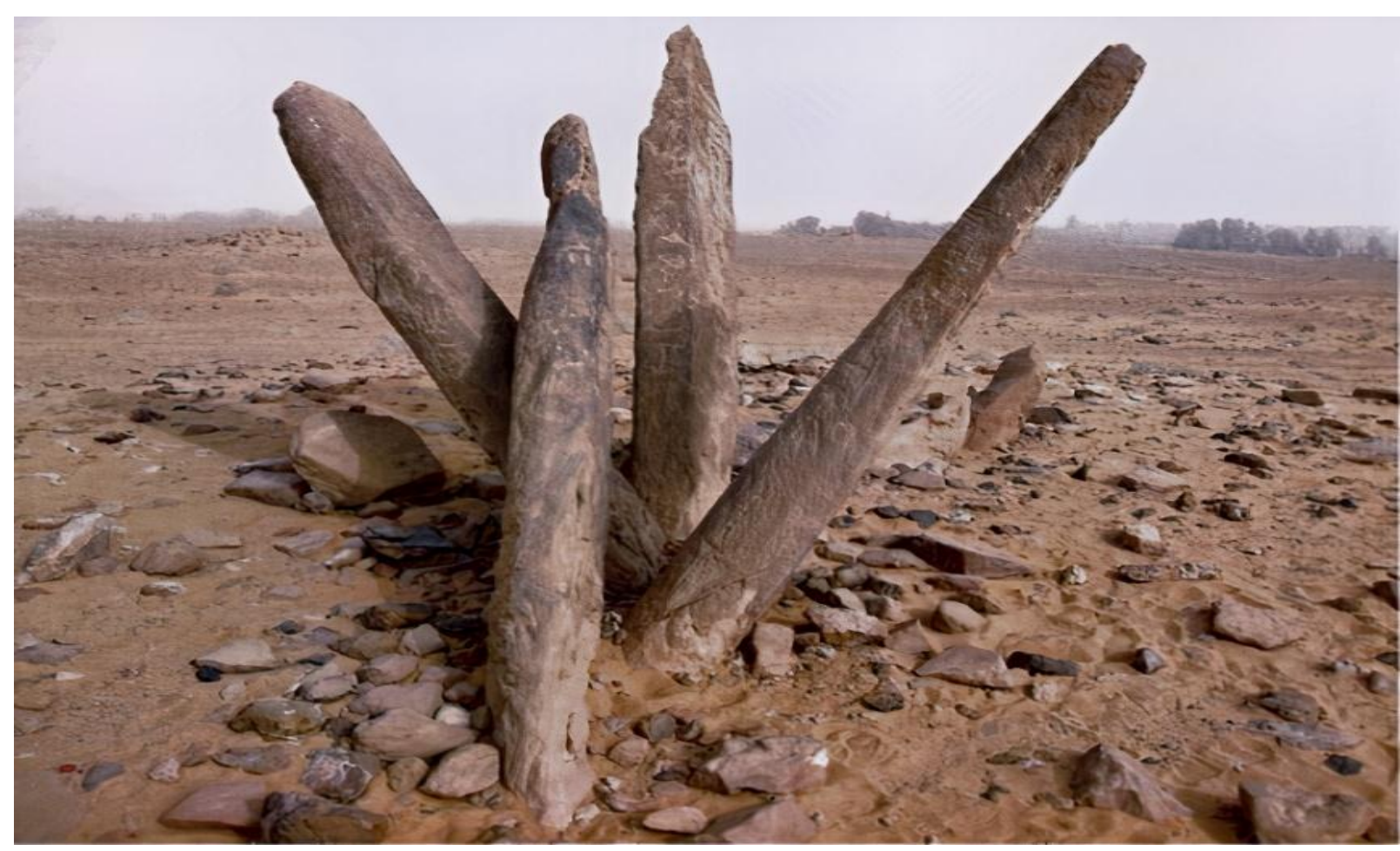

[FIGURE 9]: The stone pillars are standing, sloping or damaged into pieces.

Https://mautz.net/saudi_2019/saudi.htm, Accessed on October 2/2019.

The fourth point is the existence of some of the so-called Thamudic signs inscribed on some stone pillars of the Rajajil site. These signs are dated between the third century BC and the third century AD (see supra). The reasons mentioned above have forced people to migrate from the Rajajil site to another area. Thus, the site became abandoned for a long time. Later, some travellers or local Bedouins camped the site and reused some stone pillars as non-solid houses while the other pillars reused them as gravestones. Accordingly, some pillared burial structures in Rajajil's fenced area were reused - if not rebuilt - to serve domestic purposes later, even shortly after they lost their original function as burials. Such pillared structures have the same ground plans as in other parts of Northern Arabia, and here they represent double- or multichambered burial structures of various types and times. They left a few signs/graffiti/inscriptions on the pillars' remains. The fifth point is that the absence of organic matter among the cairns could be due to decomposition or a fire disaster.

\section{CONCLUSION}

To sum, the semi-arid and desert regions of the north-eastern Arabian Peninsula have produced a remarkable record of human occupation during the fifth millennium BC. Although many scholars have tried to give various interpretations of that mysterious site, little is known about the function of its monuments. The suggested scenario in the context of the landscape concept is that pastoral tribes chose the Rajajil site to erect their new settlement with home-style structures. They changed the lifestyle 
from «pastoralization» to «oasisisation» by using the steppe and desert to their advantage, and they adapted to the physical constraints of such landscapes. The Rajajil residents traded with their neighbours to exchange pottery and agricultural products and established the primary local civilization by erecting their buildings from stone. The stone-building activities of the people have proven the desire for stability on the site for a long time. Unfortunately, the settlement was abandoned because of drastic climate change, and later, a powerful storm destroyed the site's buildings, which became just cairns everywhere. Some stone columns, which had carried the roofs of these buildings, are still standing or sloping, fallen or been damaged into pieces. This disaster storm drifted away the artifacts of daily life to somewhere nearby. The absence of organic matter among the cairns was because of decomposition. The severe sandstorms caused the land to become barren and all the wells to run dry. The nature of the Rajajil land indicates that the sand layer covers clay soil. Such reasons may have induced people to migrate from the Rajajil site to another area. Later, some travellers or local Bedouins camped in the site and reused stone pillars as non-solid houses and other pillars as gravestones. With the same ground plans as in other areas of Northern Arabia, such pillared structures represent double- or multi-chambered burial structures of various types and times. Some of these burial structures in Rajajil's fenced area were reused - if not rebuilt - to serve domestic purposes later on, even shortly after they lost their original function as burials. The Rajajil site tells the true story of the birth and death of a local civilization that lived in the desert's silence of the Arabian Peninsula. 


\section{Mohamed Mahmoud Kacem}

\section{BIBLIOGRAPHY}

ADH-DHYYB, S.A.: Nuquš tamudīya min Sakākā, Riyadh (Maktabit al-Malk Fahd al-Wațanīya) 2002.

Al-MuAiKel, K.I.: «A Critical Study of the Archaeology of the Jawf Region of Saudi Arabia with Additional Material on its History and an Early Arabic Epigraphy». PhD Thesis, Durham University, 1988.

AlmuSHAWH, M.A.: « al-A`mida al-ḥağarīya al-manşūba fī šamāl garb al-mamlaka al- 'Arabīya al-Su ūdīya wa dilālātihā al-ḥaḍārīya», MA Thesis, King Saud University, 2016.

"An Archaeo-Astronomical Approach to the Megalithic Sites of Saudi Arabia», Mediterranean Archaeology and Archaeometry 18/4, 2018, 1-9.

CHARBONNIER, J.: «Human Adaptation in Arabia: The Role of Hydraulic Technologies», in: Climate Changes in the Holocene. Impacts and Human Adaptation, Section I: Advances in Climate Reconstruction, edited by E. CHIOTIS, 221-241, Boca Raton (Taylor \& Francis Group) 2019.

CHIOTIS, E.: «Reconstructing the Environment as a Scenery of Human History and Civilization», in: Climate Changes in the Holocene. Impacts and Human Adaptation, Section I: Advances in Climate Reconstruction, edited by E. CHIOTIS, 1-40, Boca Raton (Taylor \& Francis Group) 2019.

EDENS, C.: «The Bronze Age of Highland Yemen: Chronological and Spatial Variability of Pottery and Settlement», Paléorient 25/2, 1999, 105-128.

Gebel H.G.K. \& MAHASNeH, H.M.: «Petroglyphs and Sepulchral Contexts Preliminary Note on Late Chalcolithic/ Early Bronze Age Findings at Qulban Ban̄̄ Murra, Wadī as-Sahab al-Abyad», Journal of Epigraphy and Rock Drawings 3, 2009, 1-9.

«Disappeared by Climate Change: the Shepherd Cultures of Qulban Beni Murra ( $2^{\text {nd }}$ half of the $5^{\text {th }}$ Millennium BC) and Their Aftermath», Syria 90, 2013, 127-158.

GeBel, H.G.K. \& WeLLBROCK, K.: «Hydraulic Cultures and Hydrology under Climatic Change: North Arabian, Mid-Holocene Pastoral and Proto-Oasis Land Use», in: Climate Changes in the Holocene. Impacts and Human Adaptation, Section III: Human Responses to Climate Throughout the Holocene, edited by E. CHIOTIS, 247-270, Boca Raton (Taylor \& Francis Group)2019.

GEBEL, H.G.K.: «Arabia's Fifth-Millennium BCE Pastoral Well Cultures: Hypotheses on the Origins of Oasis Life», Seminar for Arabian Studies 43, 2013, 111-126.

GEBEL, H.G.K.: «The Socio-Hydraulic Foundations of Oasis Life in NW Arabia: The $5^{\text {th }}$ Millennium BCE Shepherd Environs of Rajajil, Rasif and Qulban Banī Murra», the Archaeology of North Arabia Oases and Landscapes. Proceedings of the International Congress held at the University, Vienna, December 5-8, 2013, edited by M. LUCIANI, 79-113, Vienna, Austrian Academy of Sciences, 2016.

GeBeL, H.G.K.: «The Origins of Oasis Life in NW Arabia. A Model Based on the Qulban Banī Murra and Rajajil Case Study Regions, and the Need of Archaeo-hydrology as a Discipline for Studying Arabia's Past», in: Proceedings of Water and Life in Arabia Conference 14-16 ${ }^{\text {th }}$ December 2014 in Abu Dhabi, edited by P. YULE, \& W.Y. AL-TiKRITI, 1-26, Abu Dhabi Tourism and Culture Authority, 2017.

GuAGNIN, M.: «Pastoralists of the Southern Nefud Desert: Inter-Regional Contact and Local Identity», in: Landscapes of Survival the Archaeology and Epigraphy of Jordan's North Eastern Desert and Beyond, edited by P. AKKERMANS, 103-116, Leiden (Side stone Press) 2020.

HAusleiter, A. \& ZuR, A.: «Taymā in the Bronze Age (c. 2000 BC): Settlement and Funerary Landscapes», the Archaeology of North Arabia Oases and Landscapes, Proceedings of the International Congress held at the University of Vienna, 5-8 December, 2013, edited by M. LuCIANI, 135174, Vienna (Austrian Academy of Sciences) 2016.

KEALL, J.: «Encountering Megaliths on the Tihamah Coastal Plain of Yemen», Seminar for Arabian Studies 28, 1998, 139-147.

KENNEDY, D.: «The 'Works of the Old Men' in Arabia. Remote Sensing in Interior Arabia», Journal of Archaeological Science 38, 2011, 3185-3203.

«The Works of the Old Men in Arabia: A Comparative Analysis», Landscapes of Survival the Archaeology and Epigraphy of Jordan's North-eastern Desert and Beyond, edited by P. AKKERMANS, 117-144, Leiden (Sidestone Press)2020. 


\section{A NeW View on the Monuments of the RajajIL Site}

KHAN, M.: «Mysteries and Mysticism in the Arabian Desert», Journal of Literature and Art Studies 4/7, 2014, 539-556.

LEWIS, R.E.: Complementizer Agreement in Najdi Arabic, MA Thesis, University of Kansas, 2013.

LORETO, R.: «New Neolithic Evidence from the al-Jawf Region: an Outline of the Historical Development of Dūmat al-Jandal», Seminar for Arabian Studies 43, 2013, 213-224.

Magee, P.: The Archaeology of Prehistoric Arabia: Adaptation and Social Formation from the Neolithic to the Iron Age, Cambridge (Cambridge University Press) 2014.

NEWTON, L.S. \& ZARINS, J.: «Aspects of Bronze Age Art of Southern Arabia: The Pictorial Landscape and its Relation to Economic and Socio-Political Status», Arabian Archaeology and Epigraphy 11, 2000, 154-179.

Punschwitz, C.: «The Prehistory of Tayma: The Chipped Stone Evidence», Zeitschrift fur OrientArchäologie 10, 2017, 288-311.

RUGGLES, C.L.N.: Astronomy in Prehistoric Britain and Ireland, New Haven (Yale University Press) 1999.

ThOMAS, H.: «The Mustatils: Cult and Monumentality in Neolithic North-western Arabia», Antiquity 95, $2021,605-626$.

ZARINS, J.: «Rajajil. Unique Arabian Site from the Fourth Millennium BC», Atlal 3, 1979, 73-77. 